\title{
Article \\ Glass-Ceramic Materials Obtained by Sintering of Vitreous Powders from Industrial Waste: Production and Properties
}

\author{
Diana M. Ayala Valderrama ${ }^{1, *(\mathbb{C}}$, Jairo A. Gómez Cuaspud ${ }^{2}\left(\mathbb{D}\right.$, Nicoletta Taniolo ${ }^{3}$ and Aldo R. Boccaccini ${ }^{3}(\mathbb{D})$ \\ 1 Comprehensive Management of Agro-industrial Productivity and Services, Universidad Santo Tomas, \\ Av. Universitaria No. 45-202, Tunja 150003, Colombia \\ 2 Institute for Research and Innovation in Materials Science and Technology, Universidad Pedagógica y \\ Tecnológica de Colombia, Av. Central del Norte 39-115, Tunja 150003, Colombia; jairo.gomez01@uptc.edu.co \\ 3 Institute of Biomaterials, Department of Materials Science and Engineering, University of \\ Erlangen-Nuremberg, 91058 Erlangen, Germany; nicolettatoniolo1990@gmail.com (N.T.); \\ aldo.boccaccini@ww.uni-erlangen.de (A.R.B.) \\ * Correspondence: diana.ayala@usantoto.edu.co; Tel.: +573-208095886
}

Citation: Ayala Valderrama, D.M.; Cuaspud, J.A.G.; Taniolo, N.; Boccaccini, A.R. Glass-Ceramic Materials Obtained by Sintering of Vitreous Powders from Industrial Waste: Production and Properties. Constr. Mater. 2021, 1, 63-79. https:// doi.org/10.3390/constrmater1010004

Received: 13 February 2021

Accepted: 28 April 2021

Published: 10 May 2021

Publisher's Note: MDPI stays neutral with regard to jurisdictional claims in published maps and institutional affiliations.

Copyright: (c) 2021 by the authors. Licensee MDPI, Basel, Switzerland. This article is an open access article distributed under the terms and conditions of the Creative Commons Attribution (CC BY) license (https:// creativecommons.org/licenses/by/ $4.0 /)$.

\begin{abstract}
Glass-ceramics are advanced inorganic silicate materials that can be obtained by sintering glass powders using a careful temperature control to result in the densification, nucleation, and crystallization of the material. In the current work, three different samples were obtained starting from amorphous silicate materials derived from mixtures of metallurgical slag, coal fly ash, and glass cullet, mixed in different proportions. The as-received waste samples were heat-treated to high temperatures to achieve complete melting at 1200,1300 , and $1400{ }^{\circ} \mathrm{C}$ for two hours, performing a rapid cooling in order to yield an amorphous material (glass). The obtained frit was ball-milled to a powder, which was then cold pressed to obtain compact pellets. The thermal treatment of pellets was carried out at $800-1100{ }^{\circ} \mathrm{C}$ for $2 \mathrm{~h}$ followed by a cooling rate of $10^{\circ} \mathrm{C} / \mathrm{min}$ to obtain the final glassceramics. The microstructure of samples was evaluated with scanning electron microscopy (SEM), which showed heterogeneous conglomerates and clusters of $\sim 20$ microns. The formation of crystalline phases was corroborated by means of X-ray diffraction (XRD) analysis, showing the presence of anorthite in all samples. Depending on the sample composition, other crystalline phases such as augite, enstatite, and diopside were detected. Using the Debye-Scherrer equation, it was possible to find the average size of the nano-crystalline domains. The quantification of the non-crystalline or amorphous fraction was also performed. Additionally, the density and porosity of the materials were calculated using the procedures defined in the ASTM C373 and ASTM C20 standards, measuring density values in the range $2.2-3.1 \mathrm{~g} \cdot \mathrm{cm}^{-3}$. The apparent porosity was approx. $33 \%$ in the three materials. Raman spectroscopy analysis showed characteristic signals associated with crystalline phases containing alumina, silica, iron, and calcium. Overall, the study confirmed the possibility of obtaining glass-ceramics with fine (nanometric) crystal sizes from a combination of silicate waste and the capability of modifying the crystalline composition by changing the proportions of the different wastes in the initial formulations.
\end{abstract}

Keywords: glass-ceramics; fly ash; glass cullet; slag; sintering; crystallization

\section{Introduction}

The incorporation of industrial waste in the production processes has established itself as an excellent alternative to the final disposal of this type of waste, focused on minimizing the impact of the use of natural resources when waste materials are used to manufacture new products [1-3]. In this research, we focus on the use of three types of silicate industrial waste for the manufacture of glass-ceramics, namely slag, fly ash, and glass cullet. These are considered materials of great interest for applications such as construction components, fire resistant materials, and high temperature refractories. The increasing interest in the field of materials manufactured using industrial waste is not only attributed to an ecological 
interest for environmental protection, but also due to the possibility of achieving new materials (e.g., glass-ceramics) with novel properties for industrial use [4-8]. The three kinds of residues embraced in this research are suitable by-products for the production of glass-ceramic materials because they contain valuable oxides such as silica $\left(\mathrm{SiO}_{2}\right)$ and alumina $\left(\mathrm{Al}_{2} \mathrm{O}_{3}\right)$, which are required for the production of mechanically stable refractory materials. The use of glass cullet is advantageous due to its high amount of silica and its high surface reactivity, while slag and fly ash are attractive due to their high content of aluminosilicates, representing one of the main advantages in the valorization of industrial byproducts [3].

The use of fly ash, slag, and glass cullet has been considered in previous research as an attractive starting point for the development of cost-effective glass-ceramic products mostly by applying conventional melting technology [9-13], since the process of devitrification of the glass can be favored without the need of nucleating agents, which are substances of relatively high cost. Indeed, by-products can act as nucleating agents during the cooling process, allowing the nucleation and crystallization of the material to obtain glass-ceramic microstructures $[14,15]$.

Recent studies have evaluated a range of industrial waste based glass-ceramics for technical applications [16-20], including highly porous materials for thermal insulation, and glass-ceramics from coal fly ash, steel slag, and vitrified municipal solid waste incinerator bottom ash with different crystalline phases, including diopside, anorthite, augite, gehlenite, and enstatite.

This work presents an alternative manufacturing method for the production of glassceramic materials based on powder technology and heat treatments with strict temperature control, which gives rise to the nucleation and crystallization processes during the sintering of amorphous silicate powder obtained from combinations of industrial waste [5]. The obtained glass-ceramic materials exhibit similar characteristics to conventional glass-ceramic materials obtained by the traditional route in terms of crystalline phases, density, and microstructure [21-24] but with the advantages brought by powder technology.

\section{Materials and Methods}

The raw materials used in this research were metallurgical slag, coal fly ash, and glass cullet, as described in a previous report [25]. The as-received powders were crushed separately using a planetary ball mill, obtaining particle sizes below $149 \mu \mathrm{m}$ for the glass cullet, and below $75 \mu \mathrm{m}$ for the slag and fly ash. Three sample mixtures were prepared for the experiments labeled as GC1, GC2, and GC3, where GC stands for "glass-ceramic" and $(1,2,3)$ refer to the mixtures detailed in Table 1 . The chemical compositions were determined by X-ray fluorescence (XRF, ZEISS, Oberkochen, Germany), using a PANalitical MiniPal 2 spectrometer operated at $20 \mathrm{KeV}$. The structural analysis of samples after the first heat treatment was performed in an X-ray diffractometer, PANanalytical X-Pert PRO 2.2 , using $\mathrm{Cu} \mathrm{K} \alpha$ radiation, with steps of $0.020^{\circ}(2 \theta)$ in continuous mode from $2 \theta 10$ to $90^{\circ}$, while the structural analysis of samples after the annealing process was carried out in a Bruker D8 Advance diffractometer (Karlsruhe, Germany) using $\mathrm{Cu} \mathrm{K} \alpha$ radiation, $40 \mathrm{kV}-40 \mathrm{~mA}, 2 \theta=10-70^{\circ}$, step size $0.05^{\circ}$. 
Table 1. Composition (\% weight) of raw materials and chemical compositions (mole percent) of samples developed in this study.

\begin{tabular}{|c|c|c|c|c|c|c|c|c|c|c|c|c|c|c|}
\hline \multirow[b]{2}{*}{ Sample } & \multicolumn{3}{|c|}{ wt. $\%$} & \multicolumn{11}{|c|}{ Composition of Mixtures Investigated (mole \%). } \\
\hline & Slag & $\begin{array}{l}\text { Fly } \\
\text { Ash }\end{array}$ & $\begin{array}{l}\text { Glass } \\
\text { Cullet }\end{array}$ & $\mathrm{Na}_{2} \mathrm{O}$ & $\mathrm{MgO}$ & $\mathrm{Al}_{2} \mathrm{O}_{3}$ & $\mathrm{SiO}_{2}$ & $\mathrm{SO}_{3}$ & $\mathrm{~K}_{2} \mathrm{O}$ & $\mathrm{CaO}$ & $\mathrm{TiO}_{2}$ & $\mathrm{Fe}_{2} \mathrm{O}_{3}$ & Mn & Other \\
\hline GC1 & 10 & 70 & 20 & 3.627 & 1.85 & 13.64 & 66.3 & 0.8 & 0.7 & 7.1 & 1.09 & 3.924 & 0.7 & 0.285 \\
\hline GC2 & 10 & 35 & 55 & 4.914 & 3.38 & 8.161 & 66.4 & 0.6 & 0.4 & 12 & 0.64 & 2.828 & 0.7 & 0.227 \\
\hline GC3 & 55 & 35 & 10 & 1.813 & 3.12 & 11.24 & 46.9 & 0.7 & 0.5 & 20 & 1.03 & 9.686 & 3.7 & 0.927 \\
\hline
\end{tabular}

Vitreous powders were prepared by high-temperature heat treatment (melting), firstly at $1200{ }^{\circ} \mathrm{C}$, then at $1300{ }^{\circ} \mathrm{C}$, and finally at $1400{ }^{\circ} \mathrm{C}$, for $2 \mathrm{~h}$. The melting at these different temperatures was carried out separately to choose the correct melting temperature required to obtain amorphous glasses (see results below). After melting, the glass was cooled at $10^{\circ} \mathrm{C} \mathrm{min}^{-1}$ and milling was carried out to obtain powders of size $<149 \mu \mathrm{m}$. Cold pressing was then used to obtain pellets of $\sim 14 \mathrm{~mm}$ diameter and $\sim 2.5 \mathrm{~mm}$ thickness using glycerol (BioXtra $\geq 99 \%$ ) ( $5 \%$ by weight) as binder for the compaction of the powders at a compressive stress of $30 \mathrm{MPa}$. Next, the pellets were sintered, taking into account the temperatures indicated in Table 2, which were determined in accordance with differential thermal analysis (DTA) results for each material, with a cooling rate of $10^{\circ} \mathrm{C} / \mathrm{min}$. For this study, it was necessary to prepare a minimum of 26 pellets for each composition for the different physical and mechanical analyses. The step-by-step fabrication process is shown in Figure 1.

Table 2. Parameters refer to the sintering of the pellets.

\begin{tabular}{ccc}
\hline Sample & Nucleation Temperatura & Crystallization Temperature \\
\hline GC1 & $950^{\circ} \mathrm{C}$ for $2 \mathrm{~h}$ & $1100^{\circ} \mathrm{C}$ for $2 \mathrm{~h}$ \\
GC2 & $800^{\circ} \mathrm{C}$ for $2 \mathrm{~h}$ & $1050{ }^{\circ} \mathrm{C}$ for $2 \mathrm{~h}$ \\
GC3 & $850^{\circ} \mathrm{C}$ for $2 \mathrm{~h}$ & $1100^{\circ} \mathrm{C}$ for $2 \mathrm{~h}$ \\
\hline
\end{tabular}

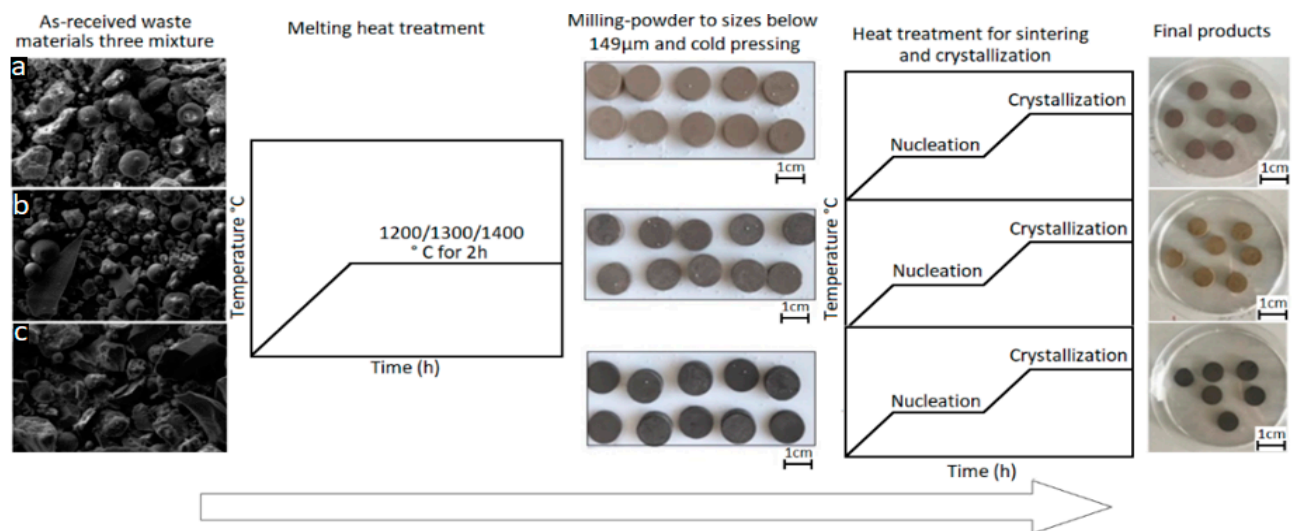

Figure 1. Scheme of the production of glass-ceramic materials obtained by sintering vitreous powders: (a) Mixture GC1, (b) Mixture GC2, and (c) Mixture GC3.

The mixtures of as-received powders, the first heat treated at $1200-1400{ }^{\circ} \mathrm{C}$, and the obtained glass-ceramic materials were examined by X-ray diffraction (XRD) analysis in powder samples (Bruker D8 Advance, Karlsruhe, Erlangen, Germany-CuK $\alpha$ radiation, $15.418 \mathrm{~nm}, 40 \mathrm{kV}-40 \mathrm{~mA}, 2 \theta=10-70^{\circ}$, step size $\left.0.05^{\circ}\right)$. The identification of phases was carried out using the GSAS software (2018, General Structure Analysis System, GSAS-2) [26]. With the data provided by XRD analysis and using the Debye-Scherrer equation [27], it was possible to find the average size of the crystalline domains in the three samples. 
Thermogravimetric analysis (DTA/TGA) was performed in a standard SDT Q600 20, DSC-TGA instrument (TA instruments, New Castle, DE, USA), using a heating rate of $10{ }^{\circ} \mathrm{C} \mathrm{min}{ }^{-1}$ under argon gas flow conditions $\left(100 \mathrm{~mL} \mathrm{~min}^{-1}\right)$ from room temperature up to $1100^{\circ} \mathrm{C}$.

Scanning electron microscopy (SEM) equipped with an energy-dispersed X-ray (SEMEDX) detector, was performed on polished samples without gold covering (LEO 435 Electron Microscope Ltd., Cambridge, UK, and Ultra Plus, Zeiss, Jena, Germany). The detailed imaging information about the morphology and surface texture of the individual particles, as well as the composition of the powder samples, were studied.

The Raman characterization was performed in a HR-UV infinity microprobe equipment (Jobin-Yvon, Paris, France) in the range of $50-1500 \mathrm{~cm}^{-1}$, with an integration time of $10 \mathrm{~s}$, accumulations of 20 Grid 600 planes/mm, using a laser source of $532 \mathrm{~nm}$, an objective $100 \times$, and a power of $50 \mathrm{~mW}$ output.

The density and porosity of the samples were calculated taking into account the procedures and standards as defined by the American Society for Testing and Materials (ASTM): ASTM C20-00 "Standard test methods for apparent porosity, water absorption, apparent specific gravity, and bulk density of burned refractory brick and shapes by boiling water," and ASTM C373 Standard "Standard test methods for determination of water absorption and associated properties by vacuum method for pressed ceramic tiles and glass tiles and boil method for extruded ceramic tiles and non-tile fired ceramic white ware products."

\section{Results}

The amorphous nature of the materials after melting was confirmed by XRD analysis (Figure 2). When the waste mixtures were heated at $1200{ }^{\circ} \mathrm{C}$ for $2 \mathrm{~h}$, the formation of peaks corresponding to crystalline phases was evident (Figure $2 \mathrm{a}-\mathrm{c}$ red color). These crystalline phases were not further characterized because such crystallized glasses were not relevant for the present study, which required amorphous materials. Therefore, it was necessary to increase the temperature to $1300^{\circ} \mathrm{C}$ for $2 \mathrm{~h}$, to obtain an amorphous material (Figure $2 \mathrm{a}-\mathrm{c}$ blue color). The same procedure was performed at $1400{ }^{\circ} \mathrm{C}$ for $2 \mathrm{~h}$ (Figure 2a-c green color) in order to rule out the possible formation of subsequent crystalline phases. It was confirmed that at both 1300 and $1400{ }^{\circ} \mathrm{C}$ amorphous materials were obtained and with the objective of obtaining glass-ceramic materials with lower production costs, $1300{ }^{\circ} \mathrm{C}$ was considered as the preferred temperature for obtaining amorphous (vitreous) material for the present investigation [28,29] from the mixtures shown in Table 1.

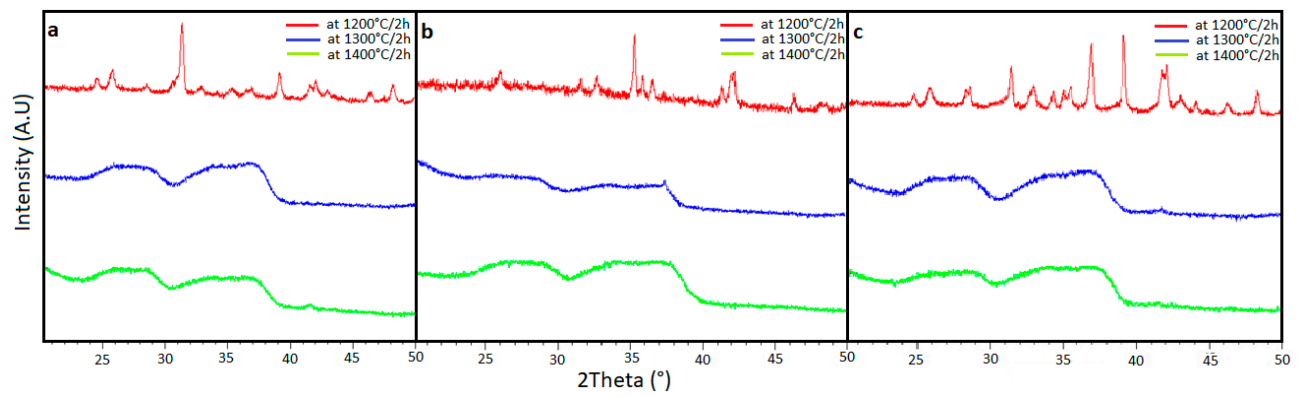

Figure 2. X-ray diffraction patterns of mixtures treated at $1200 / 1300 / 1400{ }^{\circ} \mathrm{C}$ for $2 \mathrm{~h}$ to obtain amorphous materials: (a) Sample GC1, (b) Sample GC2, and (c) Sample GC3.

The pellets obtained by cold pressing of amorphous powders were sintered as indicated in Figure 1. The temperatures were chosen according to TGA results (Figure 3) and the data presented in Table 2. Samples were characterization by XRD, SEM-EDS, Raman spectroscopy, bulk density, water absorption, and apparent porosity measurements. 


\subsection{X-Ray Diffraction (XRD) Analysis}

The effectiveness of the heat treatment for sintering and crystallization, in terms of the formation of crystalline phases, was confirmed by X-ray diffraction analysis (Figures 4-6). In any crystallization process, there are specific structural changes that generate crystalline phases. In this investigation, anorthite, augite, enstatite, and diopside in different quantities were found for each material, which are common crystalline phases in glass-ceramic materials with high aluminosilicate content [30,31].

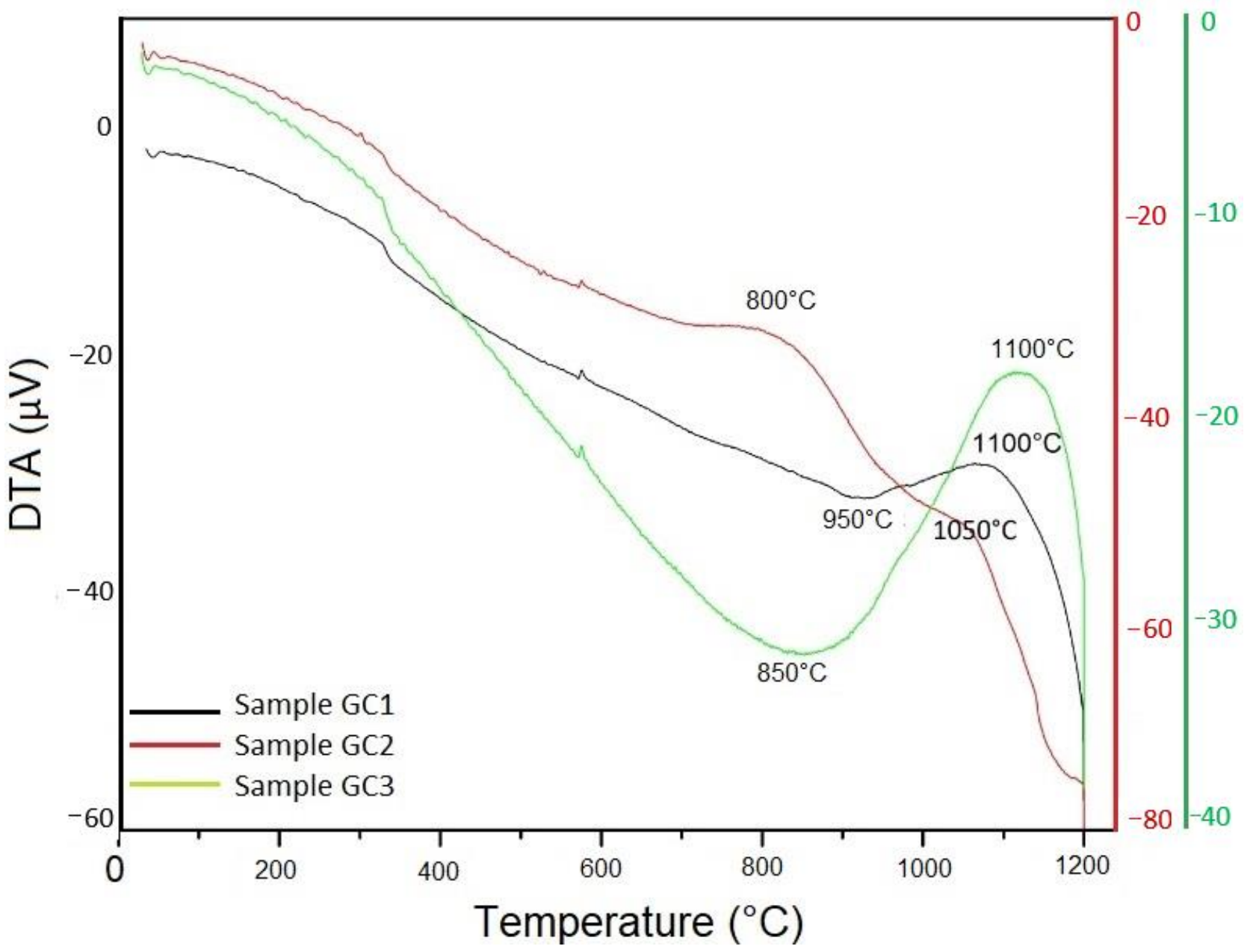

Figure 3. Differential thermal analysis profiles of GC1, GC2, and GC3 samples. 


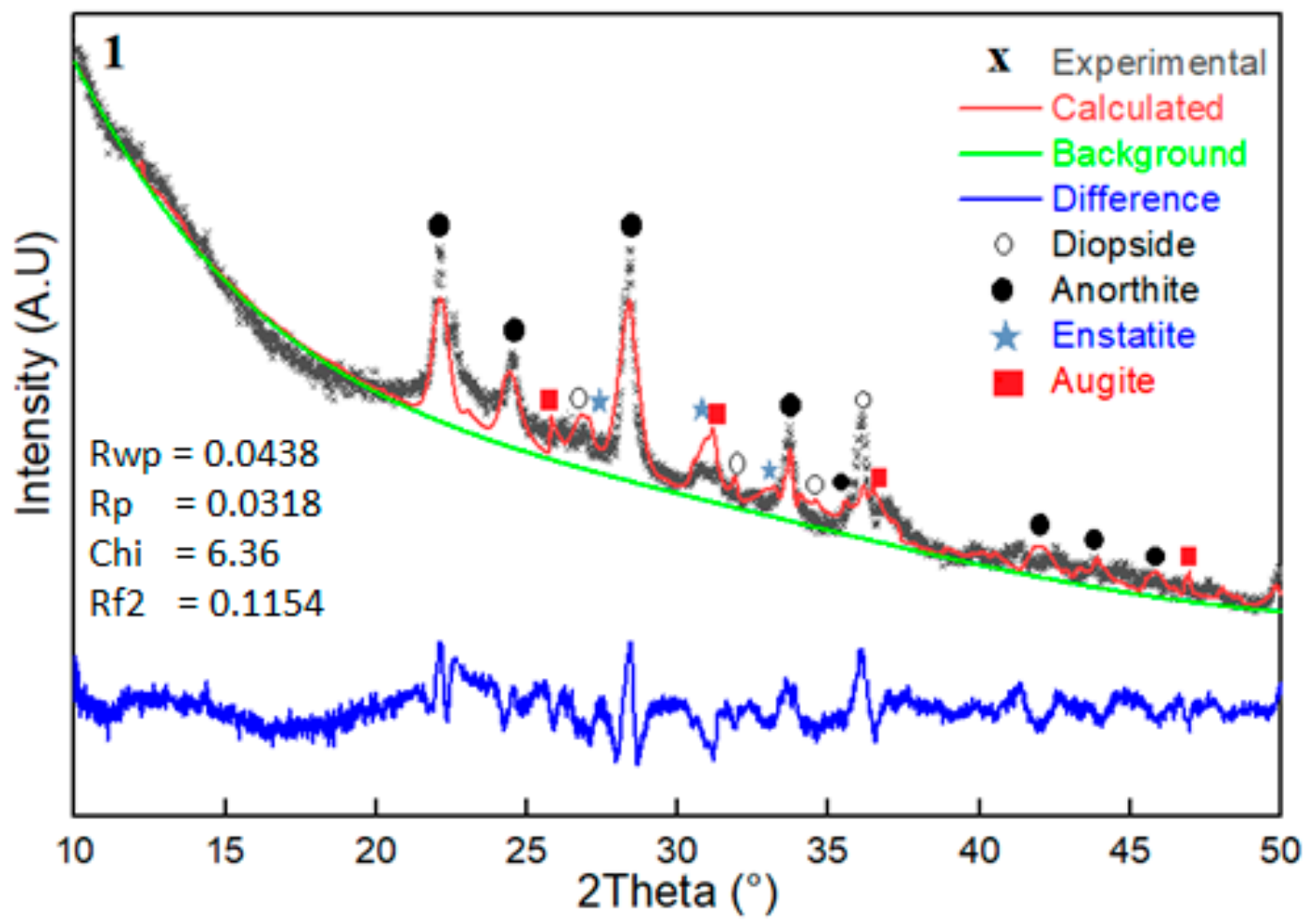

Figure 4. X-ray diffraction patterns of sample GC1 obtained at T1: $950{ }^{\circ} \mathrm{C} / 2 \mathrm{~h}$ and T2: $1100{ }^{\circ} \mathrm{C} / 2 \mathrm{~h}$ (see Table 2).

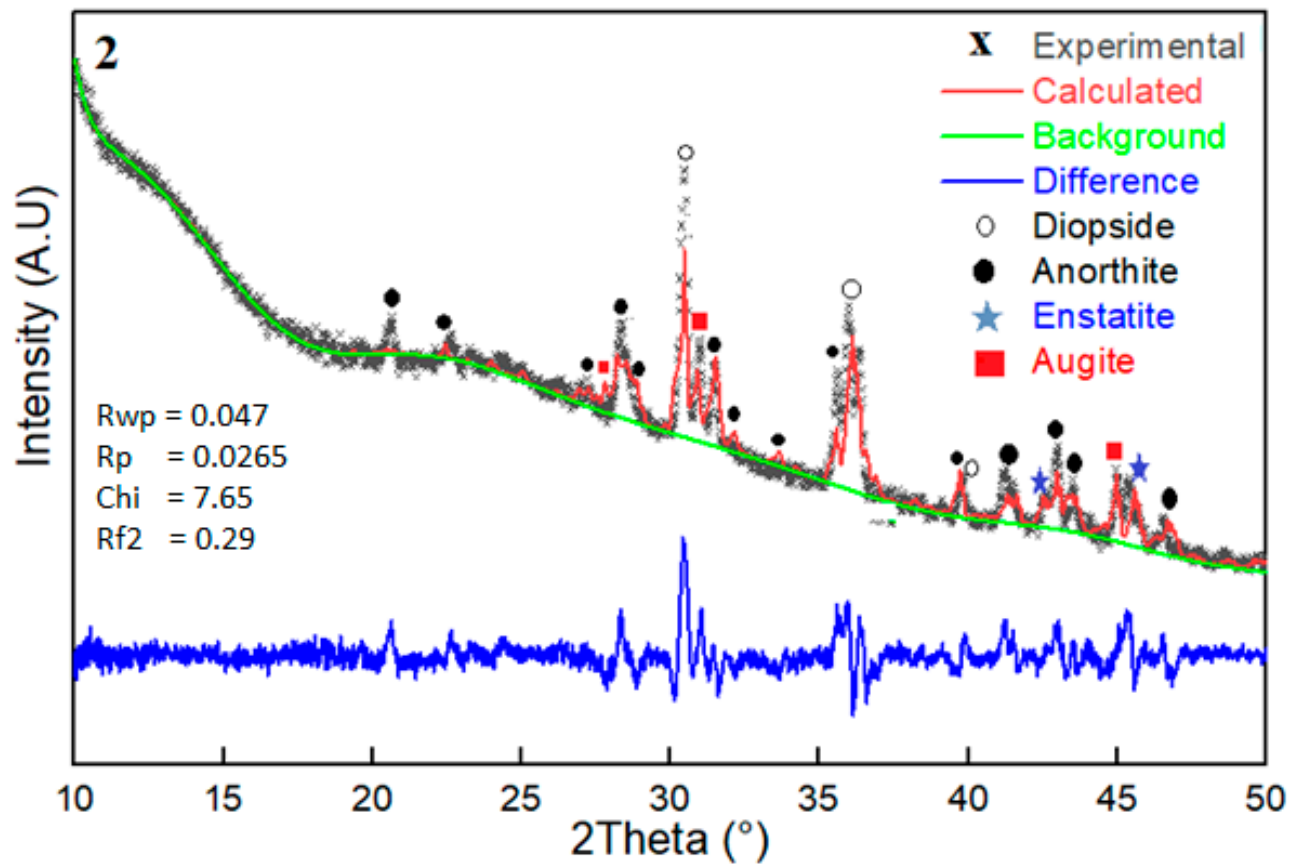

Figure 5. X-ray diffraction patterns of sample GC2 obtained at T1: $800{ }^{\circ} \mathrm{C}$ for $2 \mathrm{~h}$ and $\mathrm{T} 2: 1050{ }^{\circ} \mathrm{C}$ for $2 \mathrm{~h}$ (see Table 2 ). 


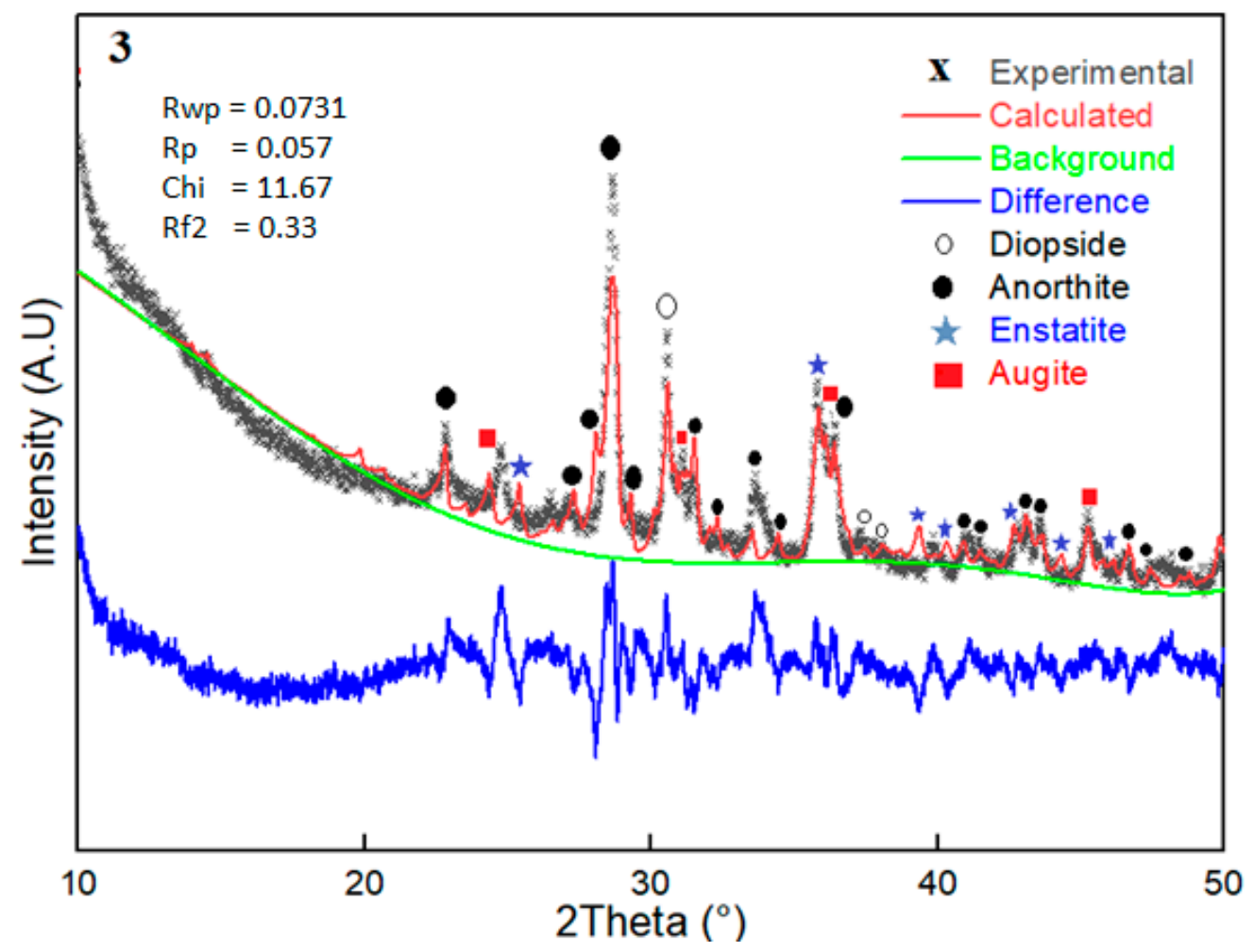

Figure 6. X-ray diffraction patterns of GC3 sample obtained at T1: $850{ }^{\circ} \mathrm{C}$ for $2 \mathrm{~h}$ and $\mathrm{T} 2: 1100{ }^{\circ} \mathrm{C}$ for $2 \mathrm{~h}$ (see Table 2 ).

The process of structural refinement was done on the individual parameters (background intensity, asymmetry, scale factor, preferential orientation, signal height and width, sample transmission and structural factor), based on experimental diffractograms [31,32]. The phases were analyzed with the crystallographic data of each phase, including as standard the cell parameters, spatial group, and atomic positions of the phase of interest.

In the sintered materials, four crystalline phases were identified in different concentrations (Figures 4-6). The diopside phase is usually present as the main phase in glass-ceramic materials obtained from the type of wastes investigated here $[4,5,33]$; however, in the present materials, the percentages of this phase were relatively low, between $5 \%$ and $15 \%$. The principal phase was anorthite, which is known to impart good mechanical properties to glass-ceramic materials according to investigations in literature [34-38], followed by the augite phase [39-41]. The enstatite phase was also identified. These phases should contribute to the mechanical properties of the present glass-ceramics; however, it is anticipated that these properties will be highly influenced by the residual porosity after sintering (see below). The composition percentages of each phase were determined in each of the sintered glass-ceramic samples summarized in Table 3. The results confirmed the crystallization of the material during the sintering process, showing the feasibility of obtaining glass-ceramic materials from the considered mixture of industrial waste by powder technology. However, the superposition of some crystalline phases that coexist in the material is evident, as for example the reflection at $2 \theta \sim 36^{\circ}$ in Figures 5 and 6, which could be associated with diopsite and augite phases, according to the refinement carried out. 
Table 3. Quantification of crystalline phases, their chemical formulas and lattice parameters of GC1, GC2, and GC3 samples.

\begin{tabular}{|c|c|c|c|c|c|c|c|}
\hline \multirow[t]{2}{*}{ Crystalline Phase } & \multirow{2}{*}{ Chemical Formula } & \multicolumn{3}{|c|}{ Lattice Parameters (Å) } & \multicolumn{3}{|c|}{$\begin{array}{c}\text { Composition Percentage }(\%) \\
\text { of Sample }\end{array}$} \\
\hline & & $\mathbf{a}$ & b & c & GC1 & GC2 & GC3 \\
\hline Anorthite & $\left(\mathrm{O}_{64} \mathrm{Ca}_{8} \mathrm{Si}_{16} \mathrm{Al}_{16}\right)$ & 8.173 & 12.869 & 12.894 & 59 & 63 & 43 \\
\hline Diopside & $\left(\mathrm{Mg}_{4} \mathrm{Ca}_{4} \mathrm{Si}_{8} \mathrm{O}_{24}\right)$ & 9.681 & 8.849 & 5.218 & 7 & 15 & 5 \\
\hline Enstatite & $\left(\mathrm{Mg}_{16} \mathrm{Si}_{16} \mathrm{O}_{48}\right)$ & 5.181 & 18.251 & 8.814 & 7 & 16 & 21 \\
\hline Augite & $\begin{array}{c}\left(\mathrm{Na}_{0,36} \mathrm{Ca}_{2,46} \mathrm{Mg}_{3,61} \mathrm{Fe}_{0,84}\right. \\
\left.\mathrm{Al}_{1,37} \mathrm{Ti}_{0,08} \mathrm{Si}_{7,28} \mathrm{O}_{24}\right)\end{array}$ & 9.699 & 8.844 & 5.272 & 27 & 6 & 31 \\
\hline
\end{tabular}

With the XRD data and using the Debye-Scherrer equation [27], the average sizes of the nano-crystalline domains of the three samples were determined, as shown in Table 4, which confirms that the sintering and crystallization process has generated glass-ceramic materials similar to those reported in literature $[4,42,43]$. The widening and low intensity of the peaks in the three diffractograms (Figures 4-6) could be correlated with the formation of small crystallites compared to the samples, due to the elimination of a large number of carbonate species in the materials as a result of the heat treatments at high temperatures and the different proportions of each silicate residue used in the starting materials.

Table 4. Crystallite size of the three samples GC1, GC2, and GC3.

\begin{tabular}{|c|c|c|c|c|c|c|c|}
\hline Sample & $2 \theta \mathrm{L}$ & $2 \theta \mathbf{H}$ & $2 \theta$ & $\theta$ & B & B(rad) & $t(n m)$ \\
\hline GC1 & 23.03 & 23.68 & 23.40 & 11.698 & 0.36 & 0.006 & 0.59 \\
\hline GC2 & 27.36 & 27.48 & 27.57 & 13.785 & 0.21 & 0.003 & 1.91 \\
\hline GC3 & 27.39 & 27.87 & 27.69 & 13.845 & 0.30 & 0.005 & 1.60 \\
\hline \multicolumn{4}{|c|}{ 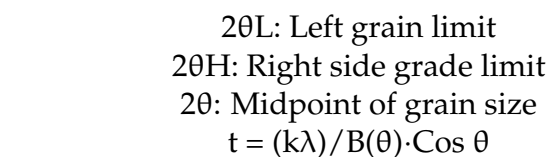 } & \multicolumn{4}{|c|}{$\begin{array}{c}\theta=2 \theta / 2 \\
B=2 \theta \mathrm{H}-2 \theta \mathrm{L} \\
\mathrm{rad})=(\mathrm{B} \cdot \pi) / 180\end{array}$} \\
\hline
\end{tabular}

The glass-ceramic materials are characterized by the presence of an amorphous and a crystalline structure. The quantification of the non-crystalline or amorphous fractions was performed using X-ray diffractograms. The analysis data software was used considering the area under the curve and excluding the areas of the signals associated with crystallization. The percentages of amorphous phases were $35 \%$ for GC1, 34\% for GC2, and $22 \%$ for GC3 samples, respectively.

\subsection{Scanning Electron Microscopy and Energy Dispersive of X-ray Spectroscopy (SEM-EDS) Analysis}

SEM-EDS was carried out to analyze the microstructure of samples before and after heat treatment. In the microstructure of the raw materials without heat treatment (Figures $7 \mathrm{a}, 8 \mathrm{a}$ and $9 \mathrm{a}$ ), it is possible to observe particles of cenospheres, glass inlays, and some agglomerates. After heat treatment at $1300{ }^{\circ} \mathrm{C}$ for $2 \mathrm{~h}$ (Figures $7 \mathrm{~b}, 8 \mathrm{~b}$ and $9 \mathrm{~b}$ ), fragments of the amorphous matrix were observed, which was corroborated by XRD analysis (Figures 4-6). 

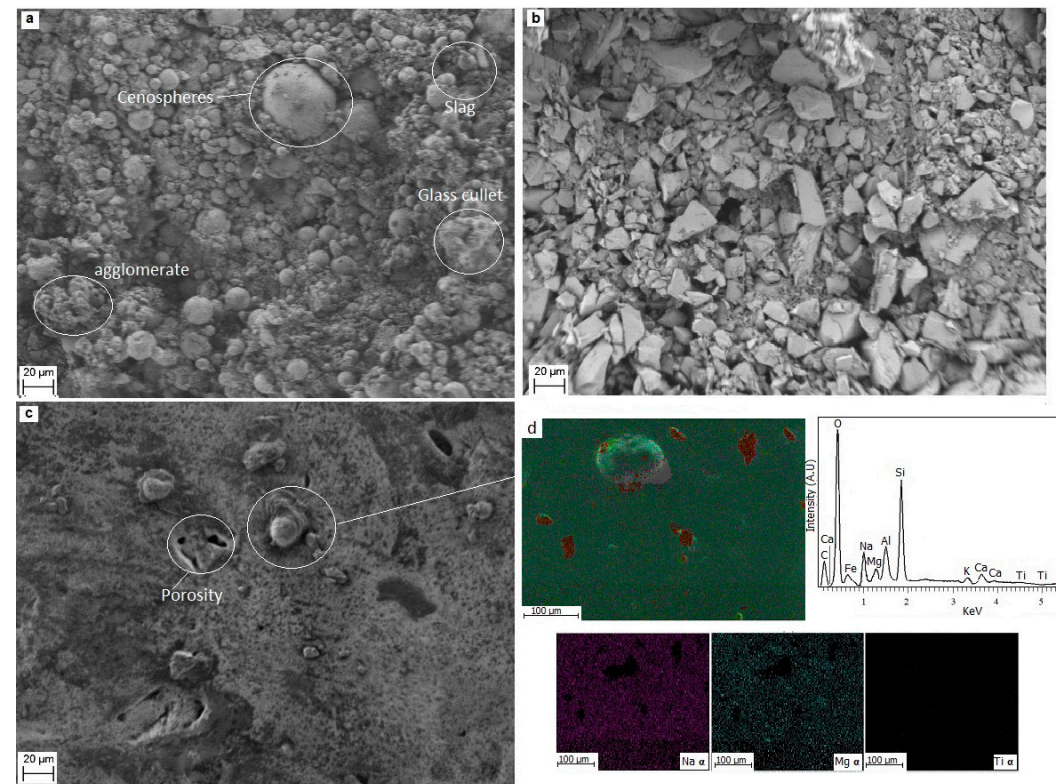

Figure 7. SEM images and EDS results of sample GC1: (a) prior to thermal treatment, (b) after thermal treatment at $1300{ }^{\circ} \mathrm{C}$ and subsequently the milling process, (c) the surface of a pellet after the sintering and crystallization process, and (d) EDS spectrum and elemental mapping of image (c).
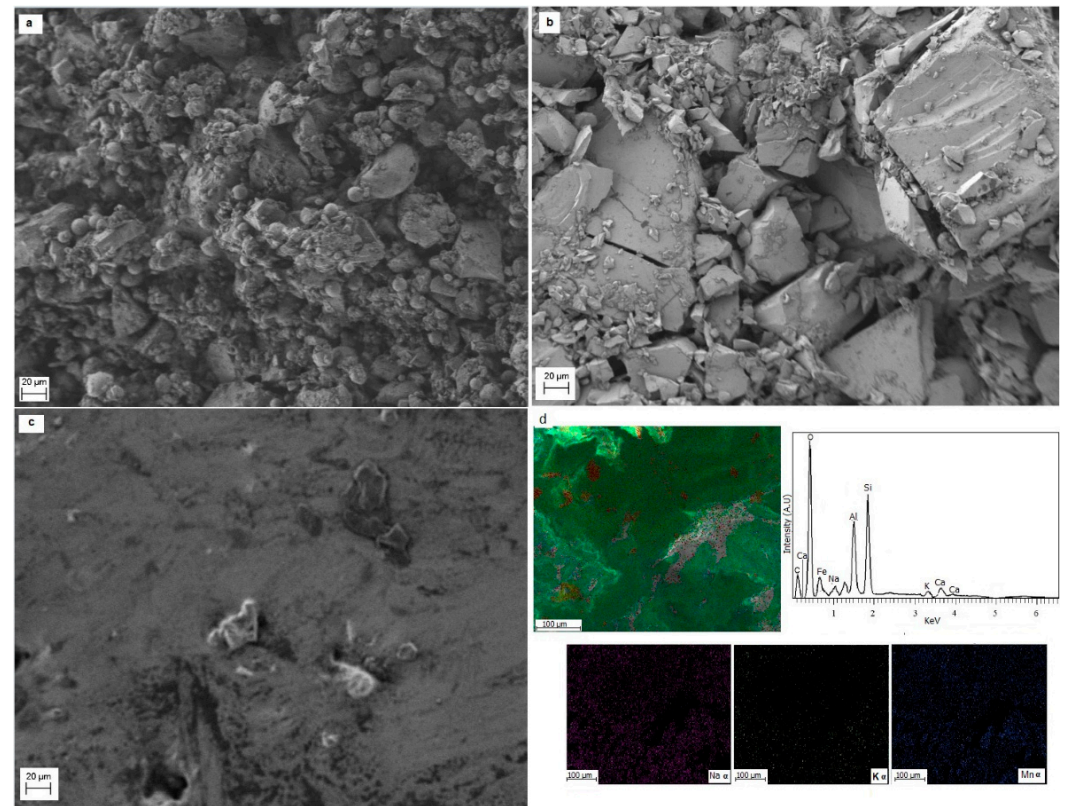

Figure 8. SEM images and EDS results of sample GC2: (a) prior to thermal treatment, (b) after thermal treatment at $1300^{\circ} \mathrm{C}$ and subsequently the milling process, (c) the surface of a pellet after the sintering and crystallization process, and (d) EDS spectrum and elemental mapping of image (c). 

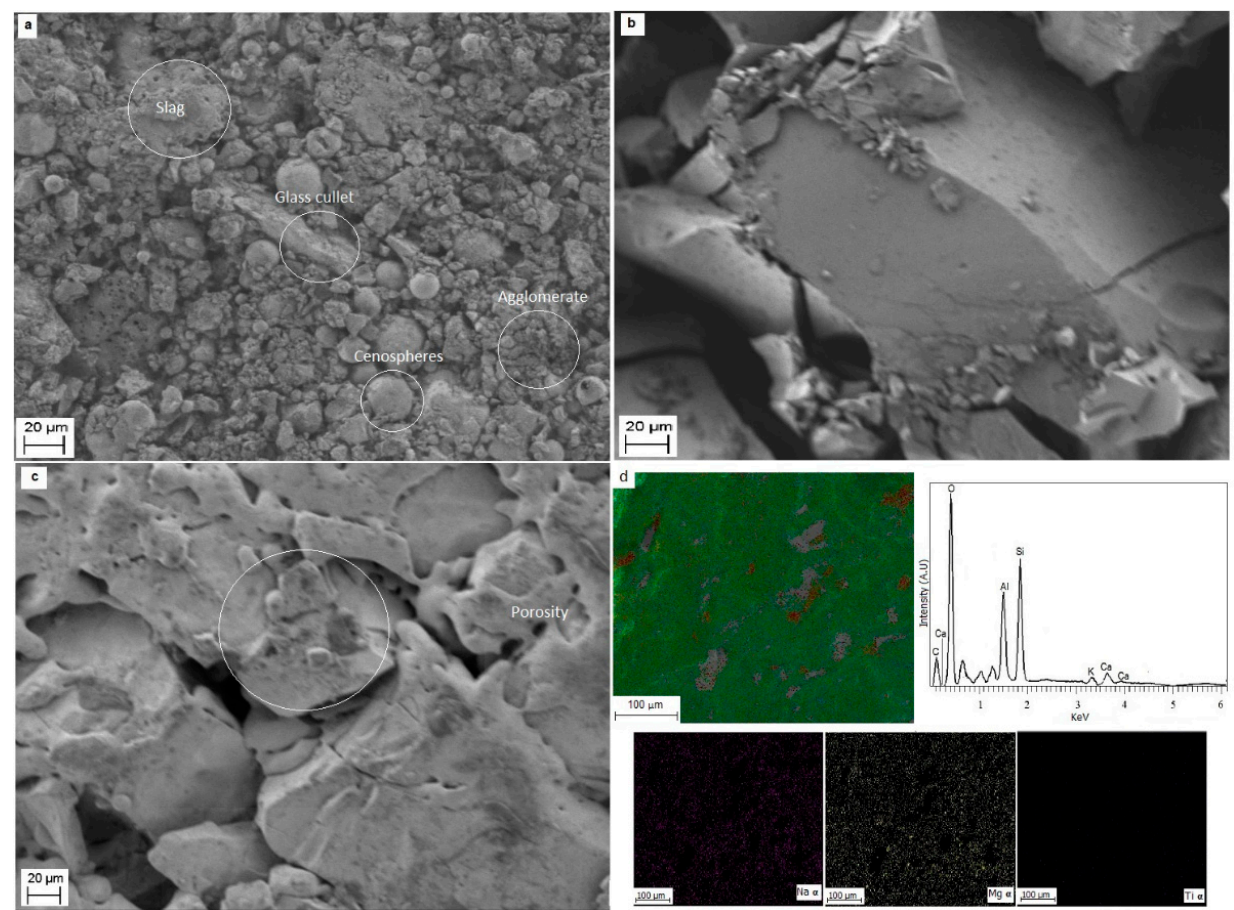

Figure 9. SEM images and EDS results of sample GC3: (a) prior to thermal treatment, (b) after thermal treatment at $1300{ }^{\circ} \mathrm{C}$ and subsequently the milling process, (c) surface of a pellet after sintering and crystallization, and (d) EDS spectrum and elemental mapping of image (c).

Figures 7-9, corresponding to SEM analysis, show heterogeneous conglomerates and residual porosity, which are typical of partially densified glass-ceramic materials obtained by sintering and crystallization of vitreous powder. Changes in the microstructure in samples GC1, GC2, and GC3 are observed in the different stages of the sintering process, as shown in Figures $7 c, 8 c$ and $9 c$. Different microstructures are visible, which may be associated with different chemical compositions of the materials, the different shades in the micrographs can represent different phases. The microstructural features observed indicate that the volume of crystallization increases with increasing temperature and heat treatment time, visualizing some areas with a bright contrast that could be located in the vitreous matrix. The areas of high contrast (Figures 7-9), according to previous research [1], could be related to crystalline phases, while the dark areas represent the amorphous phase. On the surface of all samples, scattered pores with a size of 1 to $2 \mu \mathrm{m}$ are observable, also a dense microstructure, likely consisting of crystals embedded in a residual glass matrix, is observed [44].

After the sintering process, it was possible to observe fine grains in the microstructure that apparently became embedded in a significant amount of larger particles (Figures $7 c, 8 c$ and $9 c$ ), of size $>15 \mu \mathrm{m}$, with open pores on the surface. Figures $7 d, 8 d$ and $9 \mathrm{~d}$ show EDS results for the three sintered samples, indicating the presence of $\mathrm{Si}$, $\mathrm{Al}, \mathrm{Na}$, and $\mathrm{Ca}$, as well as low amounts of other elements, such as $\mathrm{K}, \mathrm{Ti}, \mathrm{Fe}$, and $\mathrm{C}$.

The EDS analysis showed that the major constituents of sample GC1 were $\mathrm{O}, \mathrm{Si}$, $\mathrm{Al}$, and $\mathrm{Na}$ (Figure $7 \mathrm{~d}$ ). In general, the most important signals correspond to $\mathrm{Si}$ and $\mathrm{Al}$ in agreement with previous works [45]. This result is consistent with the XRD data (Table 3) which revealed that anorthite and augite were quantitatively the major crystalline phases, while enstatite and diopside showed a low concentration; therefore, the large grains observed in the SEM images (Figures 7-9) correspond to an aluminosilicate phase. Similar large grains could be found in samples GC2 and GC3 (Figures $8 \mathrm{~d}$ and 9d) in agreement with the XRD data (Table 3), which reveals that anorthite and diopside were the major crystalline phases, and enstatite and augite appear like secondary phases, present in a lower proportion ( $16 \%$ and $7 \%$, respectively). 


\subsection{Raman Spectroscopy}

The analysis by Raman spectroscopy was carried out to verify the frequencies of bond vibrations that allow the identification of the crystalline phases in the sintered samples. The results of the Raman spectroscopy measurements are shown in Table 5.

Table 5. Raman spectroscopy results for samples GC1, GC2, and GC3.

\begin{tabular}{|c|c|c|}
\hline $\begin{array}{l}\text { Band Position } \\
\left(\mathrm{cm}^{-1}\right)\end{array}$ & Possible Bond or Crystalline Phase & Ref. \\
\hline 83,85 & Anorthite pase & {$[45,46]$} \\
\hline $100-300$ & $\begin{array}{l}\text { Vibrations with a greater contribution of } \mathrm{Ca}^{2+} \text { atoms and a } \\
\text { small contribution of } \mathrm{O}_{2}\end{array}$ & {$[47]$} \\
\hline $225,270,272$ & Hematite & [48] \\
\hline 326 & Anorthite & {$[45,46]$} \\
\hline 385 & Magnetite & [48] \\
\hline $473-482$ & $\begin{array}{l}\text { Si-O-Si systems with bridge oxygen and Al-O vibrations } \\
\text { with coordination number } 4\end{array}$ & [33] \\
\hline 500 & $\begin{array}{c}\text { The movements of oxygen atoms along the union angles } \\
\text { between T-O-T }\end{array}$ & [33] \\
\hline 583 & Bending vibrations Si-O-Si, T-O-T & [49] \\
\hline $526,660,750$ & Characteristic bands of ceramic-ceramic materials & {$[45,46]$} \\
\hline 660 & Si-O-Si vibrations in $\mathrm{Q} 2$ units related to the diopside phase & {$[50,51]$} \\
\hline $611,705,872$ & Stretching calcium carbonates & {$[51,52]$} \\
\hline 710 & Indicates that there are aluminum-oxygen octahedrals & {$[53,54]$} \\
\hline 712 & Pure magnetite, located in the band $710 \mathrm{~cm}^{-1}$ in this study & {$[49,55,56]$} \\
\hline 760 & $\begin{array}{l}\text { Characteristic bands of ceramic-ceramic materials - } \\
\text { characteristic vibration of } \mathrm{Si}\end{array}$ & {$[45,46]$} \\
\hline 799 & $\mathrm{FeO}$ vibrations & [51] \\
\hline 950 & $\begin{array}{c}\text { Diopside phase given by } \mathrm{Si} / \mathrm{O} \text { vibrations }(\mathrm{Q} 2) \text { located in the } \\
\text { band } 958 \mathrm{~cm}^{-1} \text { in this study }\end{array}$ & {$[48,57]$} \\
\hline 958 & Diopside - Si/O Vibrations (Q2) & {$[49,50]$} \\
\hline 997 & Si-O-Si vibrational modes & [51] \\
\hline 1040 & Si-O-Al vibrations. & {$[49,50]$} \\
\hline
\end{tabular}

Data reported in the literature [56,58-61] show that in Raman spectra of silicate glasses, bands associated with Q4 to Q0 species (where the index denotes the number of bridging oxygens) appear at approx. $1150 \mathrm{~cm}^{-1}-\mathrm{Q} 4,1050 \mathrm{~cm}^{-1}-\mathrm{Q} 3,1000-950 \mathrm{~cm}^{-1}-\mathrm{Q} 2$, $880 \mathrm{~cm}^{-1}$-Q1, and $850 \mathrm{~cm}^{-1}-\mathrm{Q} 0$. For the sake of clarity, the three Raman spectra obtained from the sintered materials were classified into four band groups in the 80-400, 400-650, $650-850$, and $850-1500 \mathrm{~cm}^{-1}$. The bands in the range 400 to $650 \mathrm{~cm}^{-1}$ were associated with the arrangement of short-range rings of four to six members of tetrahedral $\mathrm{SiO}_{4}$ [33]. The vibrational bands along the range 650 to $850 \mathrm{~cm}^{-1}$ correspond to the Si-O-Si oxygen bridge, where there is a replacement of $\mathrm{Si}-\mathrm{O}-\mathrm{Al}$ tetrahedral structures corresponding to $\mathrm{Al}-\mathrm{O}$ vibrations with coordination number 4; the region between 850 and $1400 \mathrm{~cm}^{-1}$, corresponding to vibrations of structural units $\mathrm{Si}-\mathrm{O}-\mathrm{Si}$, where the vibrating bands are identified in the range 1000-1500 $\mathrm{cm}^{-1}$, represents typical signals in iron containing materials [33].

Structural differences are visible in the Raman spectra of the three sintered samples (GC1, GC2, and GC3), and are shown in Figures 10-12. Specifically, the frequencies of bands at $83 \mathrm{~cm}^{-1}$, identified in samples GC2 and GC3, as well as the band at position $85 \mathrm{~cm}^{-1}$ of sample GC1, correspond to materials with anorthite phase $[45,46]$. Bands between 100 and $300 \mathrm{~cm}^{-1}$ have a greater contribution of $\mathrm{Ca}^{2+}$ ions and a small contribution of $\mathrm{O}_{2}$ in the materials in accordance with Lucena et al. [47]. The bands identified at positions $270 \mathrm{~cm}^{-1}$ in sample GC1, $225 \mathrm{~cm}^{-1}$ in sample GC2, and $272 \mathrm{~cm}^{-1}$ in sample GC3 appear to correspond to hematite [48], and the band at $385 \mathrm{~cm}^{-1}$ is consistent with magnetite, despite the fact that these phases were not detected by $\mathrm{X}$-ray diffraction analysis. 


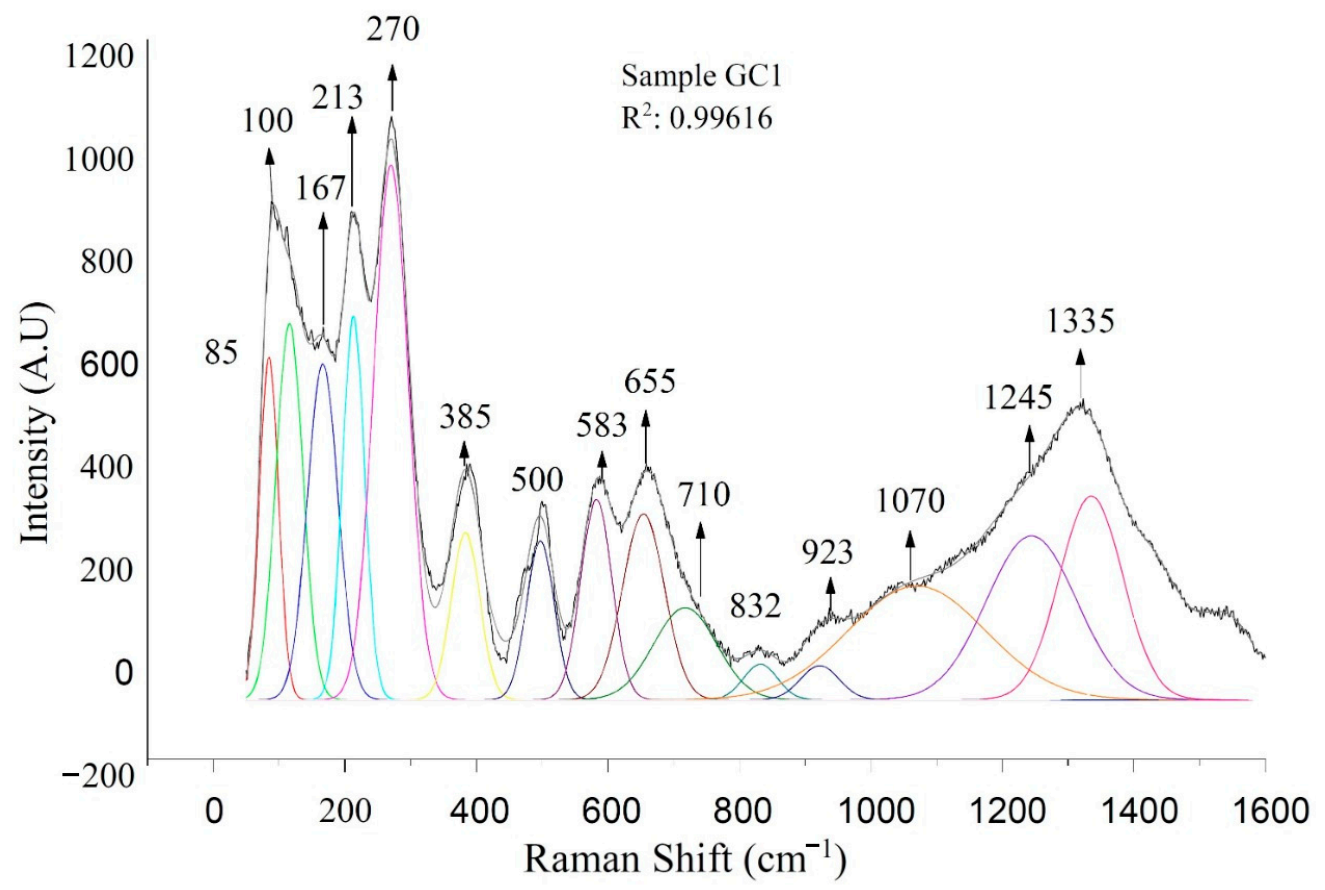

Figure 10. Raman spectrum of the sample GC1 after sintering and crystallization.

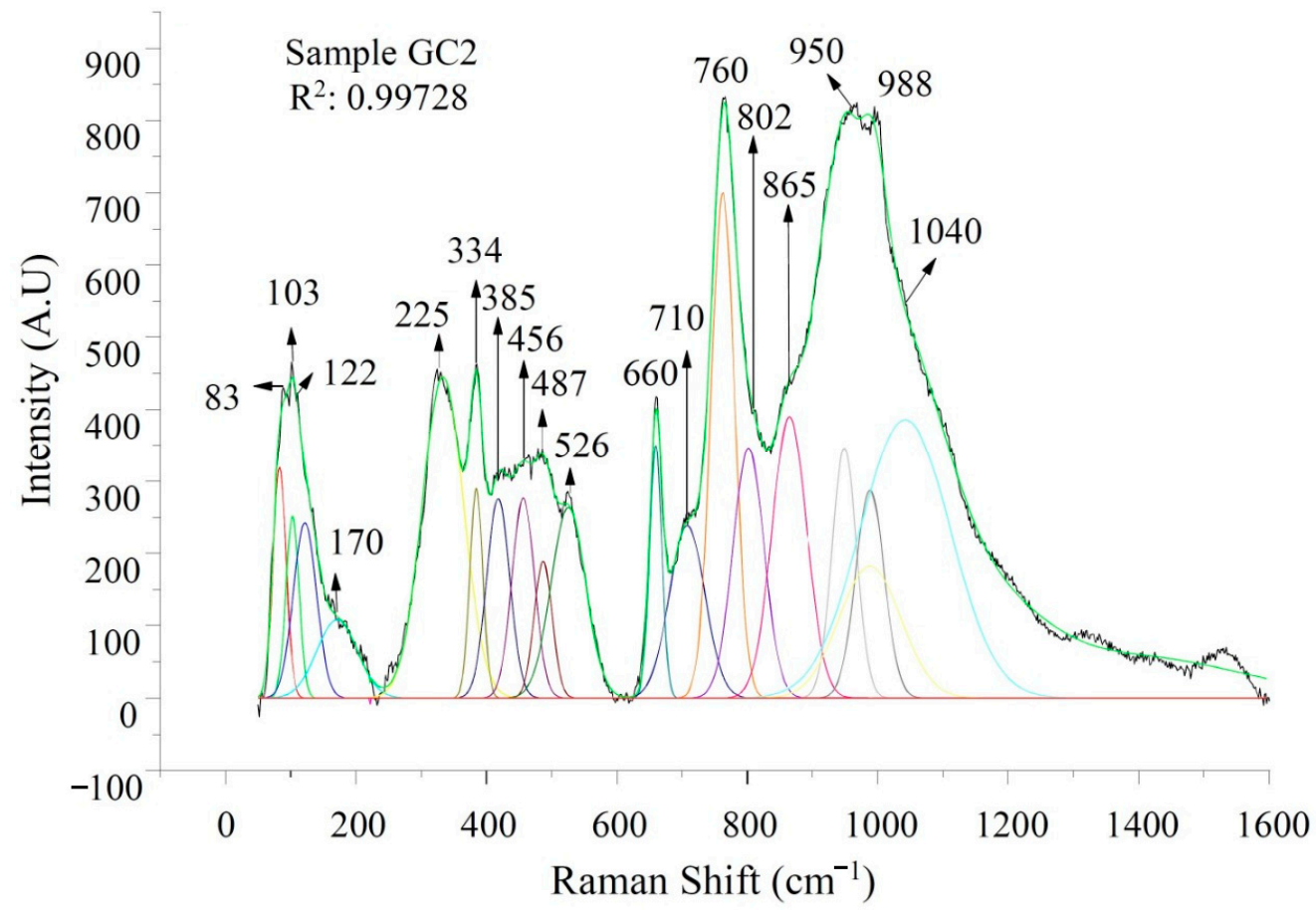

Figure 11. Raman spectrum of the sample GC2 after sintering and crystallization. 


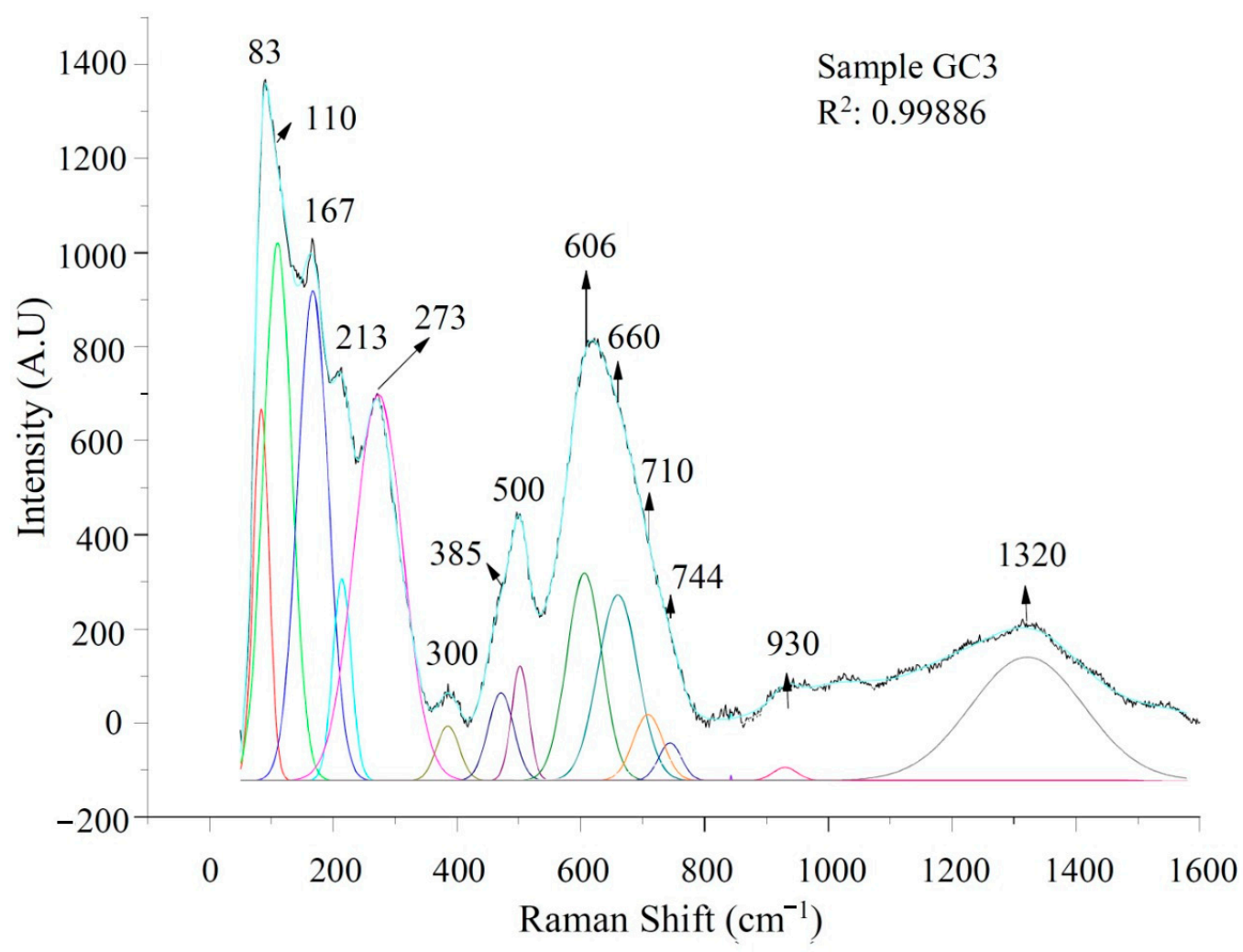

Figure 12. Raman spectrum of the sample GC3 after sintering and crystallization.

An overlap of the peaks in the diffractograms (Figures 4-6) could be the reason for the non-identification of such Fe containing phases, taking into account that according to the literature hematite should exhibit peaks at 2 theta $27^{\circ}, 28^{\circ}, 35^{\circ}$, and $36^{\circ}[62,63]$ and magnetite at around $10^{\circ}, 12^{\circ}, 15^{\circ}, 18^{\circ}$, and $35^{\circ}[59,64]$.

Despite finding a variety of documents related to Raman spectroscopy results on similar materials, the information found regarding the vibrational modes related with $1070,1245,1320$, and $1335 \mathrm{~cm}^{-1}$ signals is not clear or precise $[33,46,47,51,65]$. However, according to the XRD analysis, the observed vibratory bands exhibit a high correlation with the crystalline phases of anorthite and diopside, but they do not correspond with the enstatite and magnetite phases.

\subsection{Bulk Density, Water Absorption, and Apparent Porosity}

The density, water absorption, and apparent porosity of the glass-ceramics were experimentally measured according to the methodology described by ASTM C373 and ASTM C20. The weight of sintered GC1, GC2, and GC3 samples was measured using a balance (MODEL Kern ABS $2204 \mathrm{~N}$ ) with a tolerance of $0.01 \mathrm{~g}$. Subsequently, the samples were submerged in sufficient distilled boiling water for $5 \mathrm{~h}$ followed by $24 \mathrm{~h}$ of sowing to determine the suspended mass (S) to the nearest $0.01 \mathrm{~g}$. The samples were then dried with a piece of cotton to remove excess water on the surface. The samples were weighed for the determination of saturated mass $(\mathrm{W})[65,66]$. With the data obtained, the external volume $(\mathrm{V})$ in $\mathrm{cm}^{3}$ was obtained by subtracting the saturated mass from the suspended mass $(\mathrm{V}=\mathrm{W}-\mathrm{S})$. The volume of open porosity (VOP) can be determined from the difference between saturated mass and dry mass as follows: $(\mathrm{VOP}=\mathrm{WD})$. The apparent porosity $(\mathrm{P})$ was calculated as a percentage of open porosity data and volume as follows: $\mathrm{P}=(\mathrm{OPV} / \mathrm{V}) \times 100$. The bulk density (B) in $\mathrm{g} \cdot \mathrm{cm}^{-3}$ was determined from the ratio of dry mass (D) to external volume $(\mathrm{V})$, including pores, as follows: $\mathrm{B}=\mathrm{D} / \mathrm{V}$. An important property in glass-ceramic materials is water absorption (A), which can be expressed as a percentage of the volume ratio of open porosity and dry mass as follows: $\mathrm{A}=(\mathrm{OPV} / \mathrm{D}) \times 100$. Water impermeability was 
determined calculating the apparent specific gravity $(\mathrm{T})$. Waterproofing can be expressed as a percentage of the ratio of dry mass to suspended mass as follows: $T=D /(D-S)$.

The data obtained for the density, water absorption, and apparent porosity of samples GC1, GC2, and GC3 are shown in Table 6, including the averages of the values obtained from five samples of each material. The results were similar to previous research where glass-ceramic materials were obtained from industrial wastes with densities in the range of 1.6-3.2 $\mathrm{g} \cdot \mathrm{cm}^{-3}[5,22,66]$. In samples GC2 and GC3, the values of the density are lower in comparison to the sample GC1, which can be correlated with a decreased content of glass cullet in the starting mixture [67]. The decrease of the density in each sample could be correlated with the amount of diopside phase present in the material (GC1: 59\%, GC2: $63 \%$, and GC3: $43 \%$ ), taking into account that the density of diopside is $3.4 \mathrm{~g} \cdot \mathrm{cm}^{-3}$ [36]. Therefore, it is expected that the density increases or decreases according to the increase or decrease of this phase in the material [15].

Table 6. Density and porosity calculations of the three samples GC1, GC2, and GC3.

\begin{tabular}{ccccccc}
\hline Sample & $\begin{array}{c}\text { Dry Mass } \\
\text { (D) }(\mathbf{g})\end{array}$ & $\begin{array}{c}\text { Saturated } \\
\text { Mass } \mathbf{( W )}(\mathbf{g})\end{array}$ & $\begin{array}{c}\text { Suspended } \\
\text { Mass } \mathbf{( S )}(\mathbf{g})\end{array}$ & $\begin{array}{c}\text { Density (B) } \\
\mathbf{( g \cdot \mathbf { c m } ^ { - 3 } )}\end{array}$ & $\begin{array}{c}\text { Water Absorption } \\
\mathbf{( A )}(\mathbf{\%})\end{array}$ & $\begin{array}{c}\text { Apparent Porosity } \\
(\mathbf{P}) \mathbf{( \% )}\end{array}$ \\
\hline GC1 & 0.7 & 3.0 & 2.4 & 3.1 & 7.2 & 2.3 \\
GC2 & 1.3 & 3.1 & 2.5 & 2.2 & 14.5 & 31.7 \\
GC3 & 1.9 & 3.4 & 2.7 & 2.3 & 12.9 & 30.2 \\
\hline
\end{tabular}

The porosity and the water absorption values correlated with each other and decreased with the increase in crystallinity. The porosity and water absorption values of sample GC2 were higher than for samples GC1 and GC3, related to the degree of crystallization [23]. The porosity in the sintered materials was in the range $\sim 22-32 \%$ (Table 6 ).

Water absorption affects the performance of materials, since water penetrates into larger voids due to hydrostatic pressure, affecting the degradation rate. For this research, in GC1 specimens, the water absorption is rather low $(7.2 \%)$ compared to the samples GC2 $(14.5 \%)$ and GC3 $(12.9 \%)$. It was evident that the materials exhibited different tendencies associated with the composition. The glass cullet (55 wt.\%), fly ash (35 wt.\%), and slag $(10 \mathrm{wt} . \%)$ in sample GC2 led to an increase in porosity. In general, the result obtained in this research correlated with other works in which porous glass-ceramics have been developed [12,41].

\section{Conclusions}

Glass-ceramics based on mixtures of fly ash, waste glass, and slag were successfully obtained via powder technology and sintering. It was possible to identify an anorthitetype crystalline phase in all samples. Other crystalline phases formed were diopside, enstatite, and augite. The results of Raman spectroscopy demonstrated the presence of chemical bonds vibrations concordant with the anorthite and diopside phases, which are characteristic of this type of materials. The successful consolidation of glass-ceramic microstructures was achieved by heat treatments at temperature between 800 and $1100{ }^{\circ} \mathrm{C}$ for $2 \mathrm{~h}$. The crystal size was obtained by the Debye-Scherrer equation. The detailed characterization of the glass-ceramic materials by Rietveld refinement and Raman analysis represent and innovative aspect for the analysis of this type of industrial waste derived materials. This work demonstrated thus the possibility of obtaining glass-ceramic materials using a tailored combination of waste materials by sinter-crystallization, without using nucleating agents. 
Author Contributions: Conceptualization: A.R.B. and J.A.G.C.; methodology: D.M.A.V. and N.T.; formal analysis: D.M.A.V.; investigation: D.M.A.V.; resources: D.M.A.V., A.R.B., and J.A.G.C.; data curation: D.M.A.V. and N.T.; writing—original draft preparation: D.M.A.V.; writing-review and editing: A.R.B. and J.A.G.C.; supervision: A.R.B. and J.A.G.C.; project administration: D.M.A.V.; funding acquisition: D.M.A.V. and A.R.B. All authors have read and agreed to the published version of the manuscript.

Funding: This research was funded by Government of Boyacá-Colombian and Colciencias for financial support under Call 733 (2016) and the Institute of Biomaterials, University ErlangenNuremberg, 91058 Erlangen, Germany.

Data Availability Statement: The authors confirm that the data supporting the findings of this study are available within the article.

Acknowledgments: The authors would like to thank the Government of Boyacá and Colciencias for financial support under Call 733 (2016).

Conflicts of Interest: The authors declare to have no conflict of interest to disclose regarding the research on this paper.

\section{References}

1. Andreola, F.; Barbieri, L.; Lancellotti, I.; Leonelli, C.; Manfredini, T. Recycling of industrial wastes in ceramic manufacturing: State of art and glass case studies. Ceram. Int. 2016, 42, 13333-13338. [CrossRef]

2. Chinnam, R.K.; Francis, A.A.; Will, J.; Bernardo, E.; Boccaccini, A.R. Functional glasses and glass-ceramics derived from iron rich waste and combination of industrial residues. J. Non-Cryst. Solids 2013, 365, 63-74. [CrossRef]

3. Karayannis, V.; Moutsatsou, A.; Domopoulou, A.; Katsika, E.; Drossou, C.; Baklavaridis, A. Fired ceramics $100 \%$ from lignite fly ash and waste glass cullet mixtures. J. Build. Eng. 2017, 14, 1-6. [CrossRef]

4. Höland, W.; Beall, G.H. Glass Ceramics Technology; The American Ceramic Society: Westerville, OH, USA, 2012.

5. Rawlings, R.; Wu, J.; Boccaccini, A. Glass-ceramics: Their production from wastes-A Review. J. Mater. Sci. 2006, 41, 733-761. [CrossRef]

6. Dhir, R.; de Brito, J.; Ghataora, G.S.; Lye, C.Q. Use of Glass Cullet in Ceramics and Other Applications. Sustain. Constr. Mater. 2018, 327-387. [CrossRef]

7. Cao, J.; Lu, J.; Jiang, L.; Wang, Z. Sinterability, microstructure and compressive strength of porous glass-ceramics from metallurgical silicon slag and waste glass. Ceram. Int. 2009, 42, 10079-10084. [CrossRef]

8. Clark, T.J.; Reed, J.S. Kinetic Processes Involved in the Sintering and Crystallization of Glass Powders. J. Am. Ceram. Soc. 1986, 69, 837-846. [CrossRef]

9. Yao, Z.; Ling, T.-C.; Sarker, P.K.; Su, W.; Liu, J.; Wu, W.; Tang, J. Recycling difficult-to-treat e-waste cathode-ray-tube glass as construction and building materials: A critical review. Renew. Sustain. Energy Rev. 2018, 81, 595-604. [CrossRef]

10. Cumpston, B.; Shadman, F.; Risbud, S. Utilization of coal-ash minerals for technological ceramics. J. Mater. Sci. 1992, $27,1781-1784$. [CrossRef]

11. Park, Y.J.; Moon, S.O.; Heo, J. Crystalline phase control of glass ceramics obtained from sewage sludge fly ash. Ceram. Int. 2003, 29, 223-227. [CrossRef]

12. Gao, H.T.; Liu, X.H.; Chen, J.Q.; Qi, J.L.; Wang, Y.B.; Ai, Z.R. Preparation of glass-ceramics with low density and high strength using blast furnace slag, glass fiber and water glass. Ceram. Int. 2018, 44, 6044-6053. [CrossRef]

13. Bai, H.; Zhang, X.; Cang, D.; Zhao, L.; Wei, W. Synthesis of steel slag ceramics: Chemical composition and crystalline phases of raw materials. Int. J. Miner. Metall. Mater. 2015, 22, 325-333. [CrossRef]

14. Marinova, I.; Valencia, J.S.; Navarro, E.; Carda, J.B.; Quimicer, S.A.; Onda, D. Síntesis y caracterización de esmaltes de alto índice de refracción y dureza. Qualicer 2006, 2006, 249-260.

15. Tabit, K.; Waqif, M.; Saâdi, L. Anorthite-cordierite based binary ceramics from coal fly ash and steel slag for thermal and dielectric applications. Mater. Chem. Phys. 2020, 254, 123472. [CrossRef]

16. Li, B.; Guo, Y.; Fang, J. Effect of crystallization temperature on glass-ceramics derived from tailings waste. J. Alloy. Compd. 2020, 838, 155503. [CrossRef]

17. Tabit, K.; Hajjou, H.; Waqif, M.; Saâdi, L. Effect of $\mathrm{CaO} / \mathrm{SiO}_{2}$ ratio on phase transformation and properties of anorthite-based ceramics from coal fly ash and steel slag. Ceram. Int. 2020, 46, 7550-7558. [CrossRef]

18. Monich, P.R.; Romero, A.R.; Rambaldi, E.; Bernardo, E. Case studies of up-cycling of partially crystallized ceramic waste in highly porous glass-ceramics. Constr. Build. Mater. 2020, 261, 119971. [CrossRef]

19. Flesoura, G.; Monich, P.R.; Alarcón, R.M.; Desideri, D.; Bernardo, E.; Vleugels, J.; Pontikes, Y. Porous glass-ceramics made from microwave vitrified municipal solid waste incinerator bottom ash. Constr. Build. Mater. 2021, 270. [CrossRef]

20. Zhang, Z.; Wang, J.; Liu, L.; Ma, J.; Shen, B. Preparation of additive-free glass-ceramics from MSW incineration bottom ash and coal fly ash. Constr. Build. Mater. 2020, 254, 119345. [CrossRef] 
21. Jun Park, Y.; Heo, J. Conversion to glass-ceramics from glasses made by MSW incinerator fly ash for recycling. Ceram. Int. 2002, 28, 689-694. [CrossRef]

22. Bernardo, E.; Castellan, R.; Hreglich, S. Sintered glass-ceramics from mixtures of wastes. Ceram. Int. 2007, 33, 27-33. [CrossRef]

23. Erol, M.; Küçükbayrak, S.; Ersoy-Meriçboyu, A. Production of glass-ceramics obtained from industrial wastes by means of controlled nucleation and crystallization. Chem. Eng. J. 2007, 132, 335-343. [CrossRef]

24. Rabelo Monich, P.; Rincon Romero, A.; Höllen, D.; Bernardo, E. Porous glass-ceramics from alkali activation and sintercrystallization of mixtures of waste glass and residues from plasma processing of municipal solid waste. J. Clean. Prod. 2018, 188, 871-878. [CrossRef]

25. Ayala Valderrama, D.M.; Gomez Cuaspud, J.A.; Roether, J.A.; Boccaccini, A.R. Development and characterization of glass-ceramics from combinations of slag, fly ash, and glass cullet without adding nucleating agents. Materials 2019, 12, 2032. [CrossRef]

26. Toby, B.H. EXPGUI, a graphical user interface for GSAS. J. Appl. Crystallogr. 2001, 34, 210-213. [CrossRef]

27. Taylor, A.; Sinclair, H. On the determination of lattice parameters by the debye-scherrer method. Proc. Phys. Soc. 1945, 57, 126-135. [CrossRef]

28. Han, W. Glass ceramic of high hardness and fracture toughness developed from iron-rich wastes. Acta Metall. Sin. Engl. Lett. 2009, 22, 181-190. [CrossRef]

29. Boccaccini, A.R.; Han, W.X.; Dimech, C.; Rawlings, R.D. Glass ceramics of high hardness and fracture toughness developed from steel fly ash. Mater. Sci. Technol. 2006, 22, 1148-1154. [CrossRef]

30. Rozenstrauha, I.; Sosins, G.; Krage, L.; Sedmale, G. Elaboration of new ceramic composites containing glass fibre production wastes. Bol. Soc. Esp. Ceram. 2013, 52, 88-92. [CrossRef]

31. Gralik, G.; Chinelatto, A.L.; Chinelatto, A.S.A.; Grossa, P. Effect of different sources of alumina on the microstructure and mechanical properties of the triaxial porcelain. Cerámica 2014, 60, 471-481. [CrossRef]

32. Lara Viera, J.A. Estudio del Vitrocerámico $(1-x) L_{2} B_{4} O_{7}-x B i_{2} W 0_{6}(0<x<0.35)$ Usando el Método Rietveld; Universidad Autónoma de Nuevo León: San Nicolás de los Garza, Mexico, 2002.

33. Paucar Alvarez, C.G. Vitrocerámicos con bajo Coeficiente de Expansión Térmica Obtenidos por Sinterización con Cristalización Concurrente en Partículas Vitreas de $\mathrm{Li}_{2} \mathrm{O} . \mathrm{Al}_{2} \mathrm{O}_{3} . \mathrm{XSiO}_{2}$; Universidad Autónoma de Madrid: Madrid, Spain, 2016.

34. Daniel, I.; Gillet, P.; Ghose, S. A new high-pressure phase transition in anorthite $\left(\mathrm{CaAl}_{2} \mathrm{Si}_{2} \mathrm{O}_{8}\right)$ revealed by Raman spectroscopy. Am. Miner. 1995, 80, 645-648.

35. Cheng, X.; Ke, S.; Wang, Q.; Wang, H.; Shui, A.; Liu, P. Fabrication and characterization of anorthite-based ceramic using mineral raw materials. Ceram. Int. 2012, 38, 3227-3235. [CrossRef]

36. Ptáček, P.; Opravil, T.; Šoukal, F.; Havlica, J.; Holešinský, R. Kinetics and mechanism of formation of gehlenite, Al-Si spinel and anorthite from the mixture of kaolinite and calcite. Solid State Sci. 2013, 26, 53-58. [CrossRef]

37. Marques, V.M.F.; Tulyaganov, D.U.; Agathopoulos, S.; Gataullin, V.K.; Kothiyal, G.P.; Ferreira, J.M.F. Low temperature synthesis of anorthite based glass-ceramics via sintering and crystallization of glass-powder compacts. J. Eur. Ceram. Soc. 2006, 26, 2503-2510. [CrossRef]

38. Si, W.; Li, S. Crystallization kinetics of diopside glass ceramics. J. Phys. Conf. Ser. 2020, 1676. [CrossRef]

39. Reyes Ortiz, O.J.; Camacho Tauta, J.F. Efecto del desperdicio de una siderurgica en bases y subbases granulares. Rev. Cienc. Ing. Neogranadina 2003, 13, 25-29. [CrossRef]

40. Fernández Navarro, J. Constitución de los vidrios. Cons. Super. Investig. Cient. 1991, 1, 44-120.

41. Ghosal, S.; Self, S.A. Particle size-density relation and cenosphere content of coal fly ash. Fuel 1995, 74, 522-529. [CrossRef]

42. Liu, H.; Lu, H.; Chen, D.; Wang, H.; Xu, H.; Zhang, R. Preparation and properties of glass-ceramics derived from blast-furnace slag by a ceramic-sintering process. Ceram. Int. 2009, 35, 3181-3184. [CrossRef]

43. Yang, M.; Guo, Z.; Deng, Y.; Xing, X.; Qiu, K.; Long, J.; Li, J. International Journal of Mineral Processing Preparation of $\mathrm{CaO}-\mathrm{Al}_{2} \mathrm{O}_{3}-\mathrm{SiO}_{2}$ glass ceramics from coal gangue. Int. J. Miner. Process. 2012, 102-103, 112-115. [CrossRef]

44. Amstock, J. Manual del Vidrio en la Construcción; McGraw Hill: Mexico City, Mexico, 2011.

45. Matson, D.W.; Sharma, S.K.; Philpotts, J.A. Raman spectra of some tectosilicates and of glasses along the orthoclase-anorthite and nepheline-anorthite joins. Am. Mineral. 1986, 71, 694-704.

46. Daniel, I.; Gillet, P.; Mcmillan, P.F.; Wolf, G.; Verhelst, M.A. High-pressure behavior of anorthite: Compression and amorphization is observed which transforms the Ii polymorph into. J. Geophys. Res. 1997, 102, 10313-10325. [CrossRef]

47. Lucena, G.L.; de Lima, L.C.; Honório, L.M.C.; de Oliveira, A.L.M.; Tranquilim, R.L.; Longo, E.; de Souza, A.G.; Maia, A.d.S.; dos Santos, I.M.G. $\mathrm{CaSnO}_{3}$ obtained by modified Pechini method applied in the photocatalytic degradation of an azo dye. Cerámica 2017, 63, 536-541. [CrossRef]

48. Starbird-Pérez, R.; Montero-Campos, V. Synthesis of magnetic iron oxide nanoparticles toward arsenic removal from drinking water. Tecnol. Marcha 2015, 28, 45-54.

49. Le Parc, R.; Champagnon, B.; Dianoux, J.; Jarry, P.; Martinez, V. Anorthite and $\mathrm{CaAl}_{2} \mathrm{Si}_{2} \mathrm{O}_{8}$ glass: Low frequency Raman spectroscopy and neutron scattering. J. Non-Cryst. Solids 2003, 323, 155-161. [CrossRef]

50. Sharma, S.K.; Simons, B.; Yoder, H.S. Raman study of anorthite, calcium Tschermak's pyroxene, and gehlenite in crystalline and glassy states. Am. Mineral. 1983, 68, 1113-1125.

51. Sánchez-Polo, A.; Briceño, S.; Jamett, A.; Galeas, S.; Campaña, O.; Guerrero, V.; Arroyo, C.R.; Debut, A.; Mowbray, D.J.; Zamora-Ledezma, C.; et al. An Archaeometric Characterization of Ecuadorian Pottery. Sci. Rep. 2019, 9, 2642. [CrossRef] 
52. Montoya-Quesada, E.; Villaquirán-Caicedo, M.A.; Mejía de Gutiérrez, R.; Muñoz-Saldaña, J. Effect of ZnO content on the physical, mechanical and chemical properties of glass-ceramics in the $\mathrm{CaO}-\mathrm{SiO}_{2}-\mathrm{Al}_{2} \mathrm{O}_{3}$ system. Ceram. Int. 2020, 46, 4322-4328. [CrossRef]

53. Lu, S.G.; Kwok, K.W.; Chan, H.L.W.; Choy, C.L. Structural and electrical properties of $\mathrm{BaTi}_{4} \mathrm{O}_{9}$ microwa v e ceramics incorporated with glass phase. Mater. Sci. Eng. B 2003, 99, 6-9. [CrossRef]

54. Solids, N.; Friebele, J.; Calcium, I. Glass formation and thermal properties of low-silica calcium aluminosilicate glasses. $J$. Non-Cryst. Solids 1990, 126, 209-215.

55. Urquijo, J.P.; Casanova, H.; Morales, A.L. Engineering Iron oxide nanoparticles for biomedicine and bioengineering applications Diseño de nanopartículas magnéticas para aplicaciones en biomedicina y bioingeniería. Rev. Fac. Ing. Univ. Antoquia 2014, 71, 230-243. Available online: http:/ / www.scielo.org.co/pdf/rfiua/n71/n71a21.pdf (accessed on 7 May 2021).

56. Partyka, J. Effect of $\mathrm{BaO}$ ratio on the structure of glass-ceramic composite materials from $\mathrm{the} \mathrm{SiO}_{2}-\mathrm{Al}_{2} \mathrm{O}_{3}-\mathrm{Na}_{2} \mathrm{O}-\mathrm{K}_{2} \mathrm{O}-\mathrm{CaO}$ system. Ceram. Int. 2015, 41, 9337-9343. [CrossRef]

57. Jerez Delgado, D. Crecimiento y Caracterización de Micro y Nanoestructuras de Óxidos de Hierro y Estaño/Growth and Characterization of Iron and Tin Oxides Micro and Nanostructures. 2012. Available online: https://eprints.ucm.es/id/eprint/16 499/ (accessed on 7 May 2021).

58. Partyka, J.; Leśniak, M. Raman and infrared spectroscopy study on structure and microstructure of glass-ceramic materials from $\mathrm{SiO}_{2}-\mathrm{Al}_{2} \mathrm{O}_{3}-\mathrm{Na}_{2} \mathrm{O}-\mathrm{K}_{2} \mathrm{O}-\mathrm{CaO}$ system modified by variable molar ratio of $\mathrm{SiO}_{2} / \mathrm{Al}_{2} \mathrm{O}_{3}$. Spectrochim. Acta Part A Mol. Biomol. Spectrosc. 2016, 152, 82-91. [CrossRef] [PubMed]

59. Fan, W.D.; Yang, Q.W.; Guo, B.; Liu, B.; Zhang, S.G. Crystallization mechanism of glass-ceramics prepared from stainless steel slag. Rare Met. 2018, 37, 413-420. [CrossRef]

60. Agathopoulos, S.; Tulyaganov, D.U.; Ventura, J.M.G.; Kannan, S. Structural analysis and devitrification of glasses based on the CaO-MgO- $\mathrm{SiO}_{2}$ system with $\mathrm{B}_{2} \mathrm{O}_{3}, \mathrm{Na}_{2} \mathrm{O}, \mathrm{CaF}_{2}$ and $\mathrm{P}_{2} \mathrm{O}_{5}$ additives. J. Non-Cryst. Solids 2006, 352, 322-328. [CrossRef]

61. Chuvaeva, T.I.; Dymshits, O.S.; Petrov, V.I.; Tsenter, M.Y. Low-frequency Raman scattering of magnesium aluminosilicate glasses and glass-ceramics. J. Non-Cryst. Solids 2001, 282, 306-316. [CrossRef]

62. Blake, R.L.; Hessevic, R.E.; Zoltai, K.T.; Finger, L.W. Refinement of the Hematite Structure. Am. Mineral. 1966, 51, 123-129.

63. INEGI La Industria Minera Ampliada. p. 117, 2016. Available online: https://www.inegi.org.mx/contenido/productos/prod_ serv/contenidos/espanol/bvinegi/productos/censos/economicos/2009/mineria/Mono_Industria_Minera.pdf (accessed on 7 May 2021).

64. Haavik, C.; Stølen, S.; Fjellvåg, H.; Hanfland, M.; Häusermann, D. Equation of state of magnetite and its high-pressure modification: Thermodynamics of the Fe-O system at high pressure. Am. Mineral. 2000, 85, 514-523. [CrossRef]

65. ASTM C373-88-Standard Test Method for Water Absorption, Bulk Density, Apparent Porosity, and Apparent Specific Gravity of Fired Whiteware Products; ASTM International: Montgomery, PA, USA, 2006; pp. 1-2.

66. Nebot Diaz, I.; Marcharl, M.; Iran, M.; Carba, B.J. Nuevas Tecnologías Para el Sector Cerámico; Universitat Jaume: Valencia, Spain, 2000.

67. Radeva, V. Adaptando el método de arquímedes para determinar las densidades y porosidad de muestras pequeñas de cerámica. Cienc. Soc. 2006, XXXI, 565-585. [CrossRef] 